\title{
Content of Ascorbic Acid in Common Cowslip (Primula veris L.) Compared to Common Food Plants and Orange Juices
}

\author{
Andres Meos, Irina Zaharova, Marten Kask and Ain RaAL* \\ Institute of Pharmacy, University of Tartu, \\ Nooruse 1, Tartu 50411, Estonia
}

Received April 14, 2016; revision accepted November 27, 2016

\begin{abstract}
Ascorbic acid is a well-known antioxidant found in plants. The content of ascorbic acid was assayed using a normal phase European Pharmacopoeia HPLC method for ascorbic acid in medicinal products. The content of ascorbic acid in herbs was calculated in \% for absolutely dry drug. Ascorbic acid was not detected in the roots of Primula veris, in aerial parts it was detected in flowers $(0.43 \pm 0.034 \%)$, in blades $(1.43 \pm 0.11 \%)$ and petioles $(1.56 \pm 0.12 \%)$. In fresh leaves collected at weekly intervals the content of ascorbic acid varied from 1.19 to $2.39 \%$, being highest from mid-May to mid-June. The fresh leaves contained $2.35 \pm 0.18 \%$ of ascorbic acid and when frozen its content was quite stable for one year. The content of ascorbic acid in dried leaves decreased more than ten times in three months, in twelve months it was less than $1 / 20^{\text {th }}$ of the initial level. Compared to the analyzed common fresh fruits and salads $(n=10)$ the fresh leaves of common cowslip contained considerably more ascorbic acid. Commercial orange juices could be recommended as the most convenient source of ascorbic acid (8.6-50.4 mg/100 ml); 1-5 glasses of orange juice could fulfill the recommended daily intake of vitamin C (60 mg).
\end{abstract}

Keywords: ascorbic acid, vitamin C, Primula veris, culinary herbs, orange juice, Estonia

\section{INTRODUCTION}

Ascorbic acid (vitamin C) is a sugar acid synthesized in plants and in the liver of most vertebrates. According to Gale et al. (1995), the intake of ascorbic acid in winter was less than in summer and this was reflected in the serum levels; probably the lower plasma levels in winter increased people's susceptibility to infections. The influence of vitamin C intake on cardiovascular disease is not clear (Tomas-Barberan and Robins, 1997). Deficiency of ascorbic acid leads to scurvy, accompanied by osteoporosis and severe anemia. As a supportive medication ascorbic acid could be used in case of the following illnesses or disease states: alcoholism, arthritis, influenza, back pain, diseases of teeth and gums, dermatitis, psoriasis, bronchitis, nephritis, rheumatism, hemorrhoids, stenocardia, diabetes, atherosclerosis, jaundice, osteoporosis, prostatitis, etc. (Meos, 2003; Zilmer et al., 2006). It is also used for general strengthening of the organism and for maintaining physical and mental ability to work as well as for enhancing the capacity of the organ-

\footnotetext{
* Corresponding author, email: ain.raal@ut.ee
}

ism's resistance in the case of exhaustion or recovery period from a severe illness (Margna, 2011).

As vitamin $C$ is not synthesized in human liver, human beings must constantly supplement their diets with ascorbic acid (Ege, 1999; Dewick, 2006). It is found in many fruits and vegetables (TomasBarberan and Robins, 1997), for example in different sweet pepper cultivars, potato, green bean, tomato, quince, cucumber, marrow, peach, etc. (Dürüst et al., 1997). In addition to vegetarian diet, the organism can absorb ascorbic acid also from medicinal herbs such as common cowslip, Rosa species, blackcurrant, common sea-buckthorn, etc. (Tammeorg et al., 1975; Bunney, 1993; Raal, 2010).

Common cowslip (Cowslip primrose, Primula veris L. syn. Primula offcinalis Hill, Primulaceae) is a perennial herb with an ovate to oblong stalked leaves, which are arranged in a rosette in early spring and with deep-yellow flowers in a nodding terminal umbel. Infusions from roots and flowers of cowslip are used for respiratory infections, they have expectorant, antispasmodic and diuretic properties, the rootstock being stronger than the flowers. The flowers are mildly sedative (Bunney, 
1993). Extracts from cowslip are used due to their antiviral and anti-inflammatory activities (Huckl et al., 1999). Several saponins are isolated from roots as well as a number of uncommon and common flavonoids were found in flowers, the main flavonoids are quercetin and isorhamnetin (Huckl et al., 1999; Raal, 2010), the lipophilic flavonoids were also found in leaves (Budzianowski et al., 2005). In Estonian traditional medicine tea from leaves and flowers of cowslip has been popular against common cold and flu it was also consumed as a sedative home remedy (Raal, 2010).

A popular Estonian textbook of herbal medicines (Tammeorg et al., 1975) states that leaves of common cowslip contain up to $5.9 \%$ ascorbic acid and one leaf is enough to fulfill the recommended daily intake of vitamin $\mathrm{C}$. This amount of ascorbic acid (5.9\% of the dry weight) comes from the paper published by Ryabova in 1939 in the journal Farmatsiya edited and printed in Moscow (Ryabova, 1939). Also other studies of the content of ascorbic acid in common cowslip were performed more than half a century ago (Devyatin et al., 1943; Jastrzebski, 1956; Rakic-Mandic, 1962). Such enormous content of ascorbic acid (2.5-5.9\%) could be a result of titrimetric assay technique used in those days.

A huge amount of data about ascorbic acid content in foodstuffs and medicinal herbs is historical- ly available in scientific and popular literature, but most of them were obtained tens of years ago, primarily using error-prone redox titration methods.

In this study we try to fill this gap using an up to date normal phase HPLC method proposed by European Pharmacopoeia (Ph. Eur., 2010) for assay of ascorbic acid content in medicinal products. The goal of the present research is to study the content of ascorbic acid in common cowslip compared to common food plants and orange juices.

\section{MATERIALS AND METHODS}

\section{MATERIALS}

Common cowslip. The leaves of common cowslip were collected mostly from the same habitat in Tartu County, Nõo Parish, Village of Luke (N58 $\left.15^{\prime} 10^{\prime \prime} \mathrm{E} 26^{\circ} 34^{\prime} 20^{\prime \prime}\right)$. In order to study the influence of the habitat on the content of ascorbic acid a second batch was collected from 17 different habitats (Table 1), 12 leaves from each. All leaves were dried at room temperature.

To study the content of ascorbic acid in different parts of fresh common cowslip a whole plant was used, from which roots, blades, petioles and flowers were separated. To compare the content of ascorbic acid in leaves and flowers the material was

TABLE 1. Content of ascorbic acid in common cowslip leaves from different habitats in Estonia.

\begin{tabular}{|c|c|c|}
\hline No & Habitats & Ascorbic acid (\%) \\
\hline 1. & Harju county, Anija parish, Vetla village & $0.004 \pm 0.0003$ \\
\hline 2. & Harju county, Kuusalu parish, Kolga-Aabla village & $0.007 \pm 0.0005$ \\
\hline 3. & Harju county, Kuusalu parish, Muuksi village & $0.015 \pm 0.0010$ \\
\hline 4. & Tallinn & $0.002 \pm 0.0002$ \\
\hline 5. & Ida-Viru county, Kohtla-Järve & $0.002 \pm 0.0002$ \\
\hline 6. & Jõgeva county, Jõgeva parish, Vägeva village & $0.046 \pm 0.0040$ \\
\hline 7. & Lääne-Viru county, Kadrina parish, Kadrina township & $0.004 \pm 0,0003$ \\
\hline 8. & Lääne-Viru county, Kadrina parish, Loobu village & $0.007 \pm 0.0005$ \\
\hline 9. & Lääne-Viru county, Rakvere & $0.007 \pm 0.0005$ \\
\hline 10. & Lääne-Viru county, Tamsalu parish, Porkuni village & $0.122 \pm 0.0090$ \\
\hline 11. & Lääne-Viru county, Vihula parish, Käsmu village & $0.080 \pm 0.0060$ \\
\hline 12. & Lääne-Viru county, Väike-Maarja parish, Väike-Maarja township & $0.009 \pm 0.0007$ \\
\hline 13. & Põlva county, Räpina & $0.002 \pm 0.0002$ \\
\hline 14. & Põlva county, Valgjärve parish, Saverna village & $0.024 \pm 0.0020$ \\
\hline 15. & Tartu county, Nõo parish, Luke village & $0.004 \pm 0.0003$ \\
\hline 16. & Tartu county, Nõo parish, Nõo township & $0.057 \pm 0.004$ \\
\hline 17. & Võru county, Võru parish, Räpo village & $0.022 \pm 0.002$ \\
\hline
\end{tabular}


taken from different plants and analyzed separately. The average result of four analyzes was used.

To analyze the dynamics of ascorbic acid content during the vegetation period 12 fresh leaves were collected weekly from April $28^{\text {th }}$ to June $30^{\text {th }}$ and analyzed immediately on the day of collection. In mid-May most of the plants were blossoming and at the beginning of June the plants had mostly ceased flowering. The first signs of wilting became obvious on June $9^{\text {th }}$, at the end of June the leaves turned yellow and were covered with brown spots.

To investigate the influence of storing conditions on the content of ascorbic acid the common cowslip leaves were divided into two parts: one part was dried at room temperature and stored sealed in a plastic bag in the dark at room temperature, the other part was stored fresh in a deep freezer at $-18^{\circ} \mathrm{C}$. The content of ascorbic acid was assayed in fresh drug immediately after gathering, as well as after 3, 6, 9 and 12 months, both in dried and frozen drugs.

To study the effect of the temperature of drying, the fresh common cowslip leaves were divided into three parts and dried in a cabinet drier at room temperature, $40^{\circ} \mathrm{C}$ and $80^{\circ} \mathrm{C}$.

Spices, fruits and orange juices. To compare the content of ascorbic acid in common cowslip, fresh culinary herbs $(n=10)$, fresh fruits $(n=7)$ and commercial orange juices $(n=9)$, the plant material, fruits and juices were obtained from different supermarkets (Rimi, Konsum, Maksimarket, Prisma) in Tartu, Estonia (Table 2-3). The orange juices studied were distributed by different brands such as Aura, Cido, Kean, Largo, Põltsamaa, Rimi, Säästu, etc. The juice from the fruits was squeezed by hand.

TABLE 2. Content of ascorbic acid in fresh herbs.

\begin{tabular}{cc}
\hline Plant material & Content of ascorbic acid (\%) \\
\hline Cowslip, leaves & $1.49-3.25(\mathrm{n}=4)$ \\
\hline Chili pepper, fruits & $0.49(\mathrm{n}=1)$ \\
\hline Paprika, fruits & $0.27(\mathrm{n}=1)$ \\
\hline Spinach, aerial parts & $0.00-0.08(\mathrm{n}=3)$ \\
\hline Parsley, aerial parts & $0.00-0.07(\mathrm{n}=4)$ \\
\hline Rucola, aerial parts & $0.00-0.06(\mathrm{n}=4)$ \\
\hline Dill, aerial parts & $0.00(\mathrm{n}=4)$ \\
\hline Lettuce, aerial parts & $0.00(\mathrm{n}=4)$ \\
\hline Green onion, aerial parts & $0.00(\mathrm{n}=4)$ \\
\hline Celery, stems & $0.00(\mathrm{n}=4)$ \\
\hline Garlic, underground parts & $0.00(\mathrm{n}=4)$ \\
\hline
\end{tabular}


Luna ${ }^{\circledR}$ NH2) was used. The mobile phase was a mixture of acetonitrile and $0.05 \mathrm{M}$ aqueous solution of potassium-dihydrogenphosphate 75:25 $(\mathrm{V} / \mathrm{V})$, flow rate $1.0 \mathrm{ml} / \mathrm{min}$, column temperature $45^{\circ} \mathrm{C}$, detection wavelength $260 \mathrm{~nm}, 10 \mu \mathrm{l}$ of sample was injected. The assay was performed on an HPLC PerkinElmer Series 200 HPLC, with an autosampler and photoarray UV-detector. The system was controlled, data collected and processed by TotalChrom 6.3.2 software.

To test the system suitability, the resolution between the peaks due to ascorbic acid and impurity $\mathrm{C}$ in the chromatogram obtained with reference solution (c) (at least 3.0), as well as the signal-tonoise ratio for the peak due to impurity $C$ in the chromatogram obtained with reference solution (b) (at least 20) were determined.

We used L-ascorbic acid standard obtained from the Finnish pharmaceutical company Oriola as a pharmaceutical active substance fulfilling the requirements of European Pharmacopeia $4^{\text {th }}$ ed. (Ph. Eur., 2010, Monograph 01/2011:0253).

Daily, immediately before the assay, a $\sim 0.2 \mathrm{mg} / \mathrm{ml}$ reference solution was made with the mobile phase. To test the linearity between the concentration of the standard and the area of the corresponding peak a calibration curve was built. The correlation coefficient between these parameters within the ascorbic acid concentration range from 0.50 to $0.01 \mathrm{mg} / \mathrm{ml}$ was close to $1(\mathrm{y}=0.00000 \mathrm{x}+0.00103$, $\mathrm{R}^{2}=0.99998, \mathrm{r}=0.99999$ ).

For statistical analysis of the results basic parametric statistics were used. The data were presented as the mean value \pm standard deviation of usually 4 samples. The mean values were compared using Student's $t$-test for independent samples $(\mathrm{p}<0.05)$. A statistical method two-tail t-Test assuming equal variances was used. The sample chromatogram of common cowslip is presented in Figure 1.

\section{RESULTS AND DISCUSSION}

\section{CONTENT OF ASCORBIC ACID IN DIFFERENT FRESH PARTS OF COMMON COWSLIP}

Ascorbic acid was not detected in the roots of the common cowslip plant. In aerial parts (average content in four plants) it was detected in relatively large quantities in flowers $(0.43 \pm 0.34 \%)$ and even more in blades $(1.43 \pm 0.11 \%)$ and petioles $(1.56 \pm 0.12 \%)$ (Figure 2). According to the twotail t-Test assuming equal variances, there was no statistical difference between ascorbic acid content in blades and petioles, but there was a significant $(p<0.006)$ difference between the pooled content of ascorbic acid in blades and petioles compared to flowers. Therefore, collection of common cowslip leaves with as long as possible petioles would be reasonable and flowers could be considered as a source of ascorbic acid. It was also already mentioned by Ryabova (1939) that the plant, especially the leaves, is very rich in ascorbic acid. According to Rakic-Mandic (1962), the amount of ascorbic and dehydroascorbic acids in the underground parts of common cowslip was found in the same ratio as in the leaf.

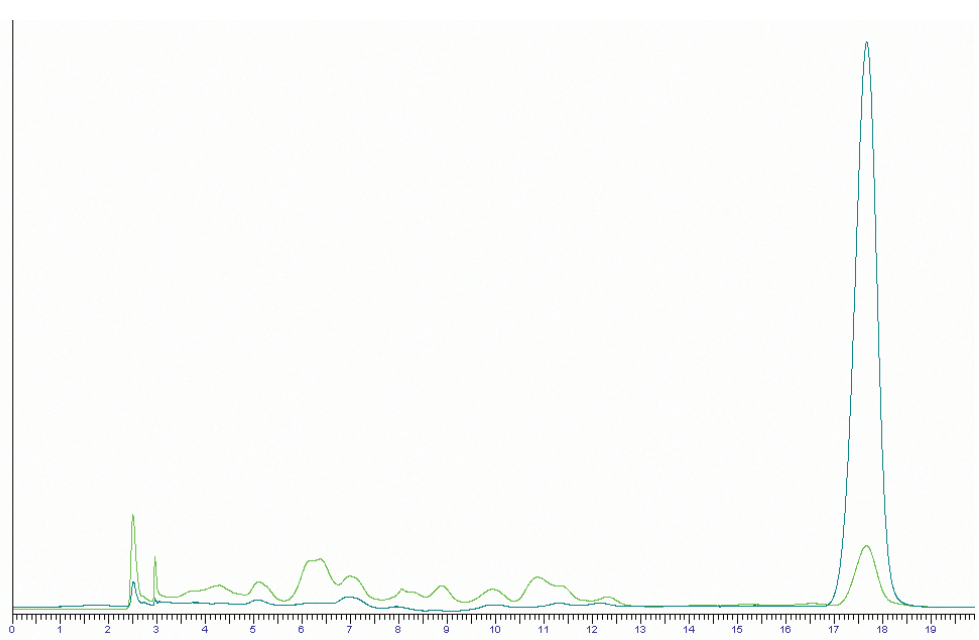

Fig. 1. Chromatogram of ascorbic acid in frozen (blue) and dried (green) leaves of common cowslip. 




Fig. 2. Content of ascorbic acid in different fresh parts of common cowslip (average content in four plants).

\section{CONTENT OF ASCORBIC ACID IN DRIED LEAVES OF COMMON COWSLIP COLLECTED FROM DIFFERENT HABITATS}

The content of ascorbic acid in the leaves of common cowslip collected from 17 different habitats, dried immediately and stored for 10 months, was generally very low - less than $0.025 \%$, i.e., about 70 times less than in fresh leaves during the vegetation period in general (Table 1). In only one sample (Tamsalu Parish, Village of Porkuni) the content reached $0.120 \%$ and in another (Vihula Parish, Village of Käsmu) up to $0.080 \%$. There is evidence that the content of ascorbic acid in dried leaves could be much more, in the range from $1.80 \%$ to $3.65 \%$, although in this study a spectro-photometric technique for quantitative determination of ascorbic acid in the dried leaves of cowslip based on its color reaction with phosphorous-molybdenum complex was used (Latypova et al., 2012). It is possible, that ascorbic acid could decompose in the process of drying or its content could vary during the vegetation period. To investigate these hypotheses we did additional experiments where the drying temperature varied and the plants were analyzed in different phases of the vegetation period.

\section{CONTENT OF ASCORBIC ACID \\ IN FRESH COMMON COWSLIP LEAVES DURING THE VEGETATION PERIOD}

In fresh common cowslip leaves collected from April $28^{\text {th }}$ to June $30^{\text {th }}$ at weekly intervals the content of ascorbic acid varied from 1.19 to $2.39 \%$, i.e., about two times (Figure 3). There was no clear tendency; it was only during the period from May $26^{\text {th }}$ to June $9^{\text {th }}$ when plants were finishing flowering that the content of ascorbic acid was insignificantly higher. Even at the end of the vegetation period, when the common cowslip leaves started to turn yellow, they contained it in a considerable amount. Samples collected from April 28, 2011 to May 19, 2011 (beginning), from May 26, 2011 to June 9, 2011 (middle) and from June 16, 2011 to June 30, 2011 (end of flowering period) were pooled and the differences between these three groups were analyzed statistically by a two-tail t-Test. In the middle phase of flowering the content of ascorbic acid was higher than at the beginning $(p<0.0005)$ or at the end $(p<0.014)$. Moreover, there was no significant difference $(\mathrm{p}<0.153)$ in the content of ascorbic acid at the beginning and end of flowering.

Based on our own earlier analyses it can be claimed that the average content of ascorbic acid in fresh cowslip leaves (1.76 $\pm 0.13 \%)$ is about 6 times higher than the value we found in dried brierberries (Rosa spp., Rosae pseudo-fructus).

It is interesting to mention that two species of cowslip ( $P$. veris and $P$. elatior) growing in Poland showed the maximum amount of ascorbic acid to be present in fresh leaves during blossoming (Jastrzebski et al., 1956). The content of ascorbic acid in dried leaves increased with the growth and

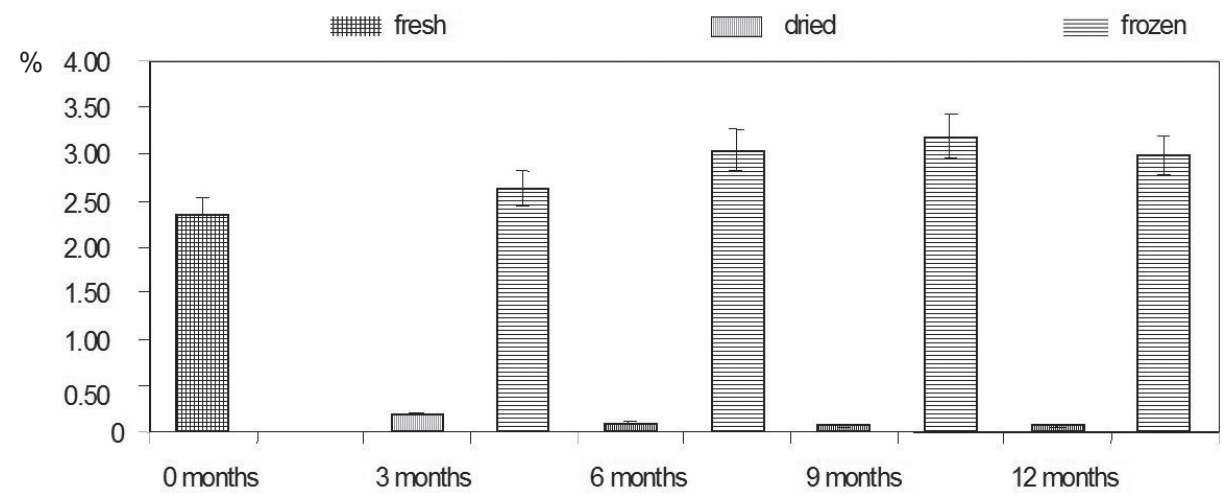

Fig. 3. Content of ascorbic acid in fresh, dried and frozen leaves of common cowslip depending on storage time. 
reached its maximum at the beginning of the shedding of blossoms.

According to Dinulica and Borz (2013), the maximum accumulation of vitamin $\mathrm{C}$ in cowslip occurred in the absence of unfavorable weather, during the 14:00-16:00 interval, in mid-May.

\section{DYNAMICS OF THE CONTENT OF ASCORBIC ACID IN DRIED AND FROZEN COMMON COWSLIP LEAVES}

Ascorbic acid was assayed in fresh drug immediately after collecting and after 3, 6, 9 and 12 months, both in dried and frozen drug. The fresh leaves contained $2.35 \pm 0.18 \%$ of ascorbic acid and when frozen its content was quite stable for one year (Figure 4). In 3 months the content of ascorbic acid in the dried leaves decreased significantly ( $\mathrm{p}<0.005$, by two-tail $t$-Test) compared to the frozen ones. During 12-month test period the content in frozen leaves did not change significantly ( $p<0.463)$, but in dried leaves it decreased in the first 3 months compared to fresh leaves $(\mathrm{p}<0.002)$ and in 6 months compared to 3 months ( $p<0.007$ ). After 6 months the change of ascorbic acid content in dried leaves was insignificant. The seeming increase of ascorbic acid content in frozen leaves could be attributed to partial evaporation of water or possible biochemical/chemical processes. At the same time the content of ascorbic acid in dried leaves decreased more than ten times in 3 months (Figure 1) and in 12 months it was less than $1 / 20^{\text {th }}$ of the initial level. The decrease was very intensive during the first 3 months, then it stabilized and there was no difference in ascorbic acid content after 9 and 12 months. According to Jastrzebski (1956), cowslip leaves contained 2.5\% ascorbic acid in freshly dried material and $2.2 \%$ after storing them for 3 months in hermetically sealed jars.

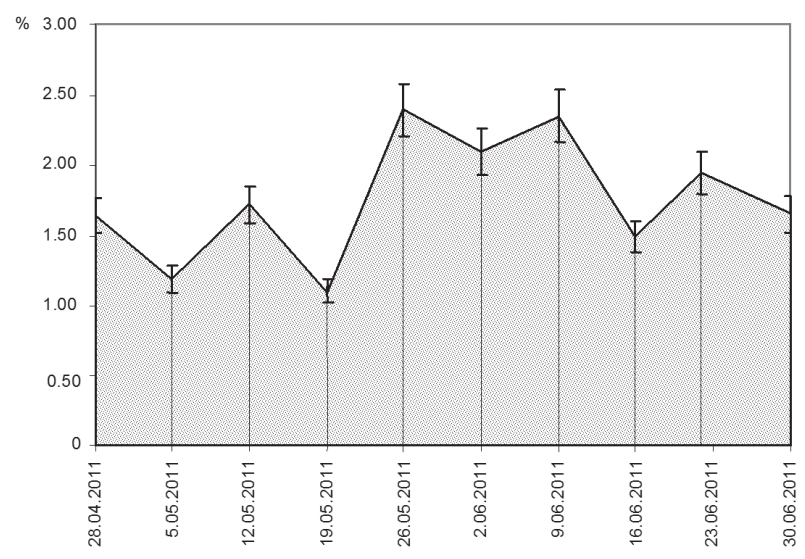

Fig. 4. Content of ascorbic acid in fresh common cowslip leaves during the vegetation period.

\section{CONTENT OF ASCORBIC ACID \\ IN A SINGLE LEAF OF COMMON COWSLIP}

Amongst Estonian herbalists there is a widespread myth that one fresh common cowslip leaf contains enough ascorbic acid to fulfill the recommended daily intake of vitamin C. The beginning of the myth could be traced back to textbooks of pharmacognosy of the early nineteen seventies, e.g., Tammeorg et al. (1975). Our data showed that the average weight of a dried cowslip leaf was $0.187 \mathrm{~g}$ (absolutely dry leaf $0.172 \mathrm{~g}$ ) and of a fresh leaf $1.100 \mathrm{~g}$ respectively. On the assumption that the average content of ascorbic acid in one leaf during a vegetation period is $1.76 \pm 0.13 \%$ calculated on absolutely dry matter, one fresh leaf could contain $\sim 3 \mathrm{mg}$. That is about 20 times less than the recommended daily intake of ascorbic acid (60 mg) (Zilmer et al., 2006). Converted to fresh leaves, the recommended daily intake should be 20-30 fresh common cowslip leaves (22-33 g).

\section{THE EFFECT OF TEMPERATURE OF DRYING ON ASCORBIC ACID CONTENT}

The drying temperature had a significant effect on the ascorbic acid content in common cowslip leaves. When dried at room temperature the content was $0.84 \pm 0.06 \%$, at $40^{\circ} \mathrm{C}$ there was almost twofold increase $-1.59 \pm 0.12 \%$, at $80^{\circ} \mathrm{C}$ the content was $2.10 \pm 0.16 \%$ (Figure 5 ). Therefore, the most suitable drying temperature would be $80^{\circ} \mathrm{C}$. Probably the increase in ascorbic acid content could be due to a shorter drying time, the substance had less time do decay. These results correlate with the recommendations of Tammeorg et al. (1975) to dry brierberries, one of the most important vitamin $\mathrm{C}$ drugs, as fast as possible at temperature $70-80^{\circ} \mathrm{C}$. The similar results were also shown by Jastrzebski (1956): drying of leaves at $50^{\circ} \mathrm{C}$ for $3-5$ hours at $65-70^{\circ} \mathrm{C}$ results in the highest retention of ascorbic acid $(2.5 \%)$, at the same time room temperature dried material contained no more than $1 \%$ ascorbic acid. According to Devyatin et al. (1943), cowslip leaves contain about $6 \%$ ascorbic acid in dry plant material and retain up to $2 / 3$ of it even after drying at $120^{\circ} \mathrm{C}$.

\section{CONTENT OF ASCORBIC ACID IN FRESH FRUITS AND SALADS}

The content of ascorbic acid was remarkable only in fresh chilli pepper and sweet pepper (Table 2) but even these plants contained 3-12 times less of ascorbic acid than common cowslip. According to Dürüst et al. (1997), sweet pepper contained about a $0.10-0.15 \%$ of ascorbic acid in dried material. Spinach, parsley and rucola are poor sources of vitamin C, practically an unreal amount of fresh 


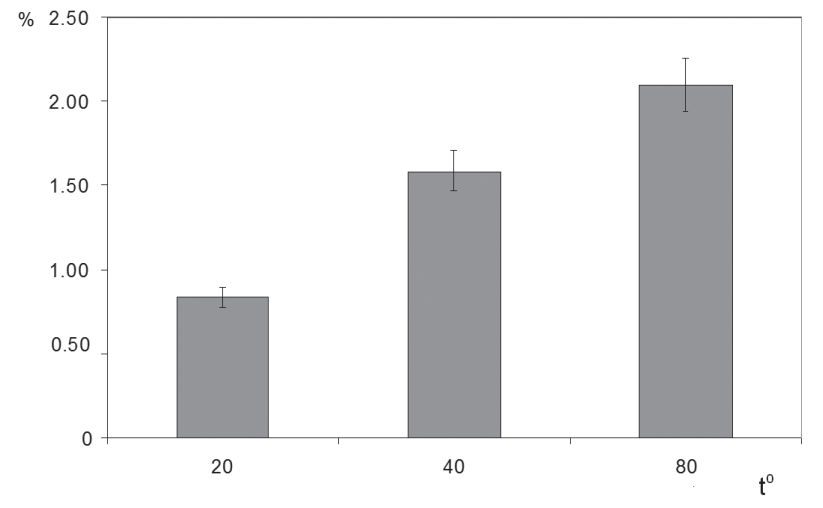

Fig. 5. Content of ascorbic acid in leaves of common cowslip depending on drying temperature.

salad (300-500 g) consisting of them can fulfill the recommended daily intake of vitamin $\mathrm{C}$. The content of ascorbic acid was not detectable in several well-known and popular herbs such as green onion, celery, dill, lettuce and garlic. Thus, fresh leaves of common cowslip may be used for making green salads rich in ascorbic acid. However, the question arises whether it can be eaten without any adverse effects. Generally, Aslam et al. (2014) concluded in their review paper that according to ethnomedical and phytochemical literature the genus Primula is a very effective and safe genus for medicinal uses. At least, according to Issa et al. (2011), the Thyme - Primulae (root) syrup was even at the highest dose non-toxic in Albino male and female rats. Because of the content of saponins the roots may be potentially more dangerous than the leaves of cowslip. Although the studies on safety or toxicity are not available for us, we suppose that cowslip-leavessalad is probably safely eatable.

Juice squeezed from fresh fruits of different citruses, especially from oranges and lemons, as well as from strawberries contained a fair amount of ascorbic acid (22-29 mg/100 ml, Table 3). On the contrary, grape juice did not contain ascorbic acid at all and its content in tomato juice was $4-5$ times less $(6 \mathrm{mg} / \mathrm{ml})$ than in citrus juice. These results allow to consider oranges as the most convenient source of ascorbic acid, although to fulfill the recommended daily intake one should eat more than one.

\section{CONTENT OF ASCORBIC ACID IN COMMERCIAL ORANGE JUICES}

The analyzed orange juices contained ascorbic acid from 8.6 to $50.4 \mathrm{mg} / 100 \mathrm{ml}$ (Table 4). This correlates to the results of Melendez-Martinez et al., 2007 who found that orange juices available in Spain contained ascorbic acid from 19.6 to
$63.4 \mathrm{mg} / 100 \mathrm{ml}$. It is remarkable that 5 samples out of 9 contained even more ascorbic acid than juice squeezed from fresh oranges $(29 \mathrm{mg} / 100 \mathrm{ml})$, especially considering the lability of ascorbic acid and the commercial "best before" time of least a year. We tried to contact the producers and ask them how they achieved such a high content of ascorbic acid for such a long period of time. The company, that produced the sample with the highest content $(50.4 \mathrm{mg} / 100 \mathrm{ml})$ answered that they routinely added ascorbic acid $(10.3 \mathrm{mg} / 100 \mathrm{ml})$ to orange juices as an antioxidant. Adding of surplus ascorbic acid could also explain the fact that in two samples with a time difference of one year from the same producer, the older sample contained only $16 \%$ less ascorbic acid than the fresher one (28.9 and $34.8 \mathrm{mg} / 100 \mathrm{ml}$, respectively). The acidic $\mathrm{pH}$ due to organic acids, especially citric acid, and lack of oxygen due to deaerated water used in production and airtight film coating cardboard containers help to preserve the ascorbic acid. Only one producer had the information about the content of ascorbic acid $(3.7 \mathrm{mg} / 100 \mathrm{ml})$ printed on the package. At the same time our analysis showed almost 3 times larger content ( $10.9 \mathrm{mg} / 100 \mathrm{ml})$, that could not be explained easily.

TABLE 4. Content of ascorbic acid in commercial orange juices.

\begin{tabular}{ccc}
\hline \hline Juice & Produced in & $(\mathbf{m g} / \mathbf{1 0 0} \mathbf{~ m l})$ \\
\hline Sample 1 & Estonia & $34.8 \pm 1.4$ \\
\hline Sample 2 & Estonia & $28.9 \pm 1.4$ \\
\hline Sample 3 & Estonia & $50.4 \pm 1.1$ \\
\hline Sample 4 & Denmark & $33.8 \pm 1.1$ \\
\hline Sample 5 & Poland & $35.1 \pm 3.7$ \\
\hline Sample 6 & Estonia & $8.6 \pm 0.6$ \\
\hline Sample 7 & Estonia & $12.9 \pm 1.3$ \\
\hline Sample 8 & Latvia & $33.1 \pm 1.8$ \\
\hline Sample 9 & Cyprus & $10.9 \pm 3.1$ \\
\hline
\end{tabular}

Altogether it could be concluded that commercial orange juice is a superb source of ascorbic acid and, depending on the producer, one to five glasses of orange juice could fulfill the recommended daily intake of vitamin $\mathrm{C}$.

\section{CONCLUSIONS}

Suitable media for extraction of ascorbic acid from herbal material is $1 \%$ aqueous solution of citric acid.

To assay the content of ascorbic acid a modified European Pharmacopoeia HPLC method for 
quantification of related substances in ascorbic acid as API could be used. It is fully suitable for quantification of ascorbic acid also in other medicinal and edible plants as well as in vegetarian food and juices and helps to break the myths about "vitamin bombs' in plants.

Common cowslip leaves could be collected during the whole vegetation period. Instead of drying the use of fresh leaves should be preferred. When long-term storage is needed, fresh leaves should be stored at $-18^{\circ} \mathrm{C}$. In case drying is inevitable, it should be done at $80^{\circ} \mathrm{C}$ and not at room temperature. In addition to leaves, flowers of common cowslip also show a considerable content of vitamin C. Compared to common and well-known fresh fruits and salads, fresh leaves of common cowslip contain considerably more ascorbic acid. As the most convenient source of ascorbic acid oranges or orange juice could be recommended.

\section{AUTORS' CONTRIBUTIONS}

$\mathrm{AM}$ and AR designed the research and supervised student IZ and pupil MK, they also drafted the manuscript. HPLC analyses of ascorbic acid were performed by AM, plant material was collected and prepared for analyses by AR with students. Common cowslip and food plants were studied by IZ and orange juices by MK. The authors of the study do not have any conflicts of interests or financial support of the study.

\section{REFERENCES}

Aslam K, Nawchoo IA, Bhat MA, Ganie AH, and Aslam N. 2014. Ethno-pharmacological review of genus Primula. International Journal of Advanced Research 2: 29-34.

Budzianowski J, Morozowska M, and WesoŁowska M. 2005. Lipophilic flavones of Primula veris L. from field cultivation and in vitro cultures. Phytochemsitry 66: 1033-1039.

Bunney S. 1993. The illustrated encyclopedia of herbs: Their medicinal and culinary uses. Chancellor Press, London.

Devyatin VA, SKorobogatova EP, and Zvorykina VV. 1943. Utilizing primrose leaves. Farmatsiya 6: 17-20.

DewICK PM. 2006. Essentials of organic chemistry. John Wiley \& Sons, West Sussex.

DinulicA F, and BorZ SA. 2013. Ecological variability of L-ascorbic acid in Primula taxa from mixed forest stands located on Postăvaru Mountain. Bulletin of the Transilvania University of Brasov 6: 15-22.

DÜRÜST N, SÜMENGEN D, and DÜRÜST Y. 1997. Ascorbic acid and element contents of foods of Trabzon (Turkey). Journal of Agricultural and Food Chemistry 45: 2085-2087.

European Pharmacopoeia. $7^{\text {th }}$ Editon. 2010. Council of Europe, Strasbourg.
Gale CR, Martyn CN, Winter PD, and Cooper C. 1995. Vitamin $\mathrm{C}$ and risk of death from stroke and coronary heart disease in cohort of elderly people. BMJ 17: 1563-1566.

Golubitski GB, BudKo EV, Basova EM, Kostarnoi AV, and IvaNOV VM. 2007. Stability of ascorbic acid in aqueous and aqueous-organic solutions for quantitative determination. Journal of Analytical Chemistry 63: 742-747.

Huckl CW, Huber CG, Lagoja IM, Ongania K-H, Scherz H, BonN GK, and Popp M. 1999. Isolation and structural elucidation of 3',4',5'-trimethoxyflavone from the flowers of Primula veris. Planta Medica 65: 491-491.

Issa A, Tarawneh R, Abu-Gharbieh, Najuar S, Salah R, AeiDaH K, Bustanji Y, and MOHammad M. 2011. In vivo acute toxicity study of Thyme - Primulae syrup. Jordan Journal of Pharmaceutical Sciences 4: 166-173.

JASTRZEBSKI M. 1956. Vitamin C content in leaves of Primula officinalis and Primula elatior. Acta Polonica Pharmaceutica 13: 493-498.

Latypova GM, BubenchiKova VN, Romanova ZR, and Galimova DF. 2012. Standartization of Primula officinalis leaves according to the indicator "Ascorbic acid content". Nautchnye vedomosti Belgorodskogo gosudarstvennogo universiteta. Seria: Meditsina. Farmacya 18: 1-6.

MARGNA U. 2011. Introduction to phytotherapy. Tallinna Tervishoiu Kõrgkool, Tallinn (in Estonian).

Melendez-Martinez AJ, Vicario IM, and Heredia FJ. 2007. Provitamin A carotenoids and ascorbic acid contents of the different types of orange juices marketed in Spain. Food Chemistry 101: 177-184.

Meos A. 2003. Lectures in pharmaceutical chemistry. Alkaloids and vitamins. Farmaatsia Instituut, Tartu (in Estonian).

RAAL A. 2010. Encyclopedia of herbs of the World. Eesti Entsüklopeediakirjastus, Tallinn (in Estonian).

RAKIC-MANDiC G. 1962. Vitamin C in Brassica oleracea and Primula officinalis. Arhiv Farmacia (Belgrade) 12: 529-534.

Ryabova OV. 1939. Primula officinalis L. as a source of vitamin C. Farmatsiya 11: 22-24.

TAMmeorg J, KooK O, and Vilbaste G. 1975. Medicinal plants of Estonian SSR. Valgus, Tallinn (in Estonian).

Zilmer M, Karelson E, Vihalemm T, Rehema A, and Zilmer K. 2006. The biomoleculs and metabolism in human body. TÜ Kirjastus, Tartu (in Estonian). 